\title{
Positive Leadership and Corporate Entrepreneurship: Theoretical Considerations and Research Propositions
}

\author{
Przemysław Zbierowski
}

\begin{abstract}
A B S T R A C T
Objective: The objective of the paper is to describe the approaches to positive leadership and propose research directions on its impact on corporate entrepreneurship. There is much debate within positive leadership domain and the question arises if positive style of leadership supports the entrepreneurship within corporations conceptualised as entrepreneurial orientation.

Research Design \& Methods: The main method employed in the paper is critical literature review. Based on that, some research propositions are formulated.

Findings: Four research propositions concern the possible impact of positive leadership on corporate entrepreneurship. It is proposed that authentic leadership, fundamental state of leadership, psychological capital and positive deviance all positively influence corporate entrepreneurship.

Implications \& Recommendations: The main implications of the paper concern future research in corporate entrepreneurship domain. Moreover, the indirect impact is expected on managerial practice in future research results concerning supporting corporate entrepreneurship by enhancing positive leadership behaviours.
\end{abstract}

Contribution \& Value Added: The paper opens new line of research on the crossroads of positive organizational scholarship research and entrepreneurship theory. The main contribution of the paper is to draw attention to the models of leadership that might be critical for entrepreneurship inside organisations.

\begin{tabular}{ll}
\hline Article type: & $\begin{array}{l}\text { conceptual article } \\
\text { corporate entrepreneurship; positive organizational scholarship; } \\
\text { positive leadership; psychological capital; authentic leadership; fun- } \\
\text { Keywords: }\end{array}$ \\
damental state of leadership; positive deviance \\
JEL codes: & L26
\end{tabular}

Received: 17 February $2016 \quad$ Revised: 14 June $2016 \quad$ Accepted: 26 July 2016

\section{Suggested citation:}

Zbierowski, P. (2016). Positive Leadership and Corporate Entrepreneurship: Theoretical Considerations and Research Propositions. Entrepreneurial Business and Economics Review, 4(3), 73-84, DOI: http://dx.doi.org/10.15678/EBER.2016.040306 


\section{INTRODUCTION}

While leadership is one of the leading issues in positive organisational scholarship (POS), there has been a lot of confusion and chaos in that regard. Moreover, rapid development of positive leadership theories has been observed in the last decade since the statement that "the understanding, developmental process, and implementation of needed positive leadership still remains largely under-researched by both the leadership and recently emerging positive psychology fields" (Luthans \& Avolio, 2003, p. 241). Additionally, few papers concern the impact of positive leadership on other phenomena at organisational level, for example firm level entrepreneurship. Therefore, the objective of the paper is to describe the approaches to positive leadership and propose research directions on its impact on corporate entrepreneurship of firms. The objective is of theoretical and practical importance, as the debate on supporting entrepreneurship in enterprises are being looked for by managers. The question of style of leadership that enhances corporate entrepreneurship is in line with very recent research directions proposed by leading scholars (Levie, 2016).

The paper presents the theory of positive organisational scholarship (POS) with the focus on positive leadership. Some of the leadership concepts preceding POS but corresponding to it are presented as well, such as transformational leadership or servant leadership. The main body of the paper presents three positive leadership concepts: fundamental state of leadership, authentic leadership and positive deviance. Moreover, the construct of psychological capital (PsyCap) is presented. Additionally, research propositions on impact of positive leadership on corporate entrepreneurship are presented. The research was carried out within research project 2014/13/B/HS4/01618 funded by National Science Centre in Poland.

As the paper is of conceptual nature the main method applied is critical literature review. The material for this review are mainly papers and book chapters published under the banner of positive organisational scholarship, however, the review is not limited to that sources. The main purpose of literature review is to uncover the processes in which positive leadership contributes to entrepreneurship inside organisations and to formulate research propositions. The paper does not list the studies undertaken in this regard before, as they are not available.

\section{LITERATURE REVIEW AND THEORY DEVELOPMENT}

\section{Positive Organisational Scholarship and Positive Leadership}

POS is an umbrella concept and has its main inspiration in positive psychology that proposes different perspective, not replacing traditional approach, but attempting to supplement it. It redirects focus from what is wrong with people toward emphasizing human strengths that allow people to build the best in live, thrive and prosper. POS proposes a new philosophy of organisation. While it doesn't reject the organisational and social phenomena, such as greed, selfishness, manipulation, distrust or anxiety, it emphasizes the "positive" ones, e.g. appreciation, collaboration, virtuousness, vitality, meaningfulness, trustworthiness, resilience, wisdom, loyalty, respect and honesty (Cameron, Dutton \& Quinn, 2003; Cameron \& Spreitzer, 2012). POS proposes new approach both in ontolo- 
gy and epistemology of organisational science, it sheds new light on what organisation is and how to get to know it. It is not a single theory, more of a viewpoint putting emphasis on positive and dynamic social and organisational phenomena, encompassing attention "to the enablers (e.g., processes, capabilities, structures, methods), the motivations (e.g., unselfishness, altruism, contribution without regard to self), and the outcomes or effects (e.g., vitality, meaningfulness, exhilaration, high-quality relationships) associated with positive phenomena" (Cameron et al., 2003, p. 4).

Cameron and Spreitzer (2012) argue that the convergence in understanding positivity can be summarized in four approaches: (1) adopting a unique lens or an alternative perspective that puts more emphasis on positive phenomena and attributes more importance to them, (2) focusing on extraordinarily positive outcomes or positively deviant performance, outcomes dramatically exceeding common or expected performance, (3) an affirmative bias that fosters resourcefulness - elevating the resources in individuals, groups, and organisations to build capacity, and (4) the examination of virtuousness or the best of the human condition with eudaemonic assumption.

The careful analysis of the POS underlying philosophy brings to a conclusion that at the core of focus of the notion are human strengths that result in extraordinary organisational performance. Moreover, founders of POS always stress the critical importance of uplifting interpersonal relationships, especially relationships between leaders and their followers (Quinn, 2005; Cameron, 2008). POS scholars also refer to some earlier leadership theories developed mainly in 1970s, especially to transformational leadership and servant leadership.

\section{Pre-Pos Positive Leadership Approaches}

Transformational leadership theory stresses the fact, that leadership is a process by which a person interacts with others and is able to create a relationship that results in a high degree of trust, that will later result in an increase of motivation, both intrinsic and extrinsic of both leaders and followers. The core of transformational leadership theories is the assumption that leaders transform their followers (instead of just transacting with them as in transactional theories) through their inspirational nature and charismatic personality. Rules and regulations are flexible, guided by group norms. These attributes provide a sense of belonging for the followers as they can easily identify with the leader and its purpose. Transformational leadership theory rests on the assertion that certain leader behaviours can arouse followers to a higher level of thinking (Bass, 1985; Burns, 1978). By appealing to followers' ideals and values, transformational leaders enhance commitment to a well-articulated vision and inspire followers to develop new ways of thinking about problems (Piccolo \& Colquitt, 2006).

Probably the most wide-spread model of transformational leadership was proposed by Bass (1985). He was interested in the extent to which a leader influences followers. Followers go after a leader because of trust, honesty, and other qualities and the stronger these are, the greater loyalty they have for the leader. The leader transforms the followers because of having these qualities. Not only is the leader a role model, but he exhorts the followers to challenge the existing order, the revolutionary being a stark example of this. While the leader may have democratic motives in mind, he can assume a transaction leadership style at the same time, directing the followers to do things. Bass stressed following aspects of transformational leadership: (1) Individual consideration is 
the degree to which leaders attend to followers' needs, act as mentors or coaches, and listen to followers' concerns. Individual consideration, where there is an emphasis on what a group member needs. The leader acts as a role model, mentor, facilitator, or teacher to bring a follower into the group and be motivated to do tasks. (2) Intellectual stimulation is the degree to which leaders challenge assumptions, take risks, and solicit followers' ideas. Intellectual stimulation is provided by a leader in terms of challenge to the prevailing order, task, and individual. Leader seeks ideas from the group and encourages them to contribute, learn, and be independent. The leader often becomes a teacher. (3) Inspirational motivation is the degree to which leaders articulate visions that are appealing to followers. Inspiration by a leader means giving meaning to the follows of a task. This usually involves providing a vision or goal. The group is given a reason or purpose to do a task or even be in the organisation. The leader will resort to charismatic approaches in exhorting the group to go forward. (4) Idealized influence is the degree to which leaders behave in charismatic ways that cause followers to identify with them. Idealized influence refers to the leader becoming a full-fledged role model, acting out and displaying ideal traits of honesty, trust, enthusiasm and pride.

Servant leadership philosophy was founded by Greenleaf in the essay "The Servant As Leader". Greenleaf (1977), a practitioner with a forty-year career in AT\&T, compiled his observations to stimulate dialogue and build a better, more caring society. He described himself as a lifelong student of organisations and how things get done (Greenleaf, 1977, p. 336). Although Greenleaf (1977) never formally defined servant-leadership, others have described it as valuing individuals and developing people, building community, practicing authenticity, and providing leadership that focuses on the good of those who are being led and those whom the organisation serves. The strength of servantleadership in encouraging follower learning, growth, and autonomy "suggests that the untested theory will play a role in the future leadership of the learning organisation" (Bass, 2000, p. 31).

\section{Main Positive Leadership Approaches}

As said before, leadership is one of the leading topics in positive organisational scholarship. However, a couple of partly competing and partly supplementing each other theories have been developed in the last decade and a half that introduces some degree of disorder. Probably the most widespread approach is that of authentic leadership. It was also the only positive leadership theory included in original POS foundation book by Cameron et al. (2003): "this is the only chapter in this book on positive organisational scholarship that deals directly with leadership, and there are no entries in the recently published Handbook of Positive Psychology" (Luthans \& Avolio, 2003, p. 241).

Authenticity itself is one of the pillars of positive organisational scholarship. All the other phenomena discussed within POS have no value and meaning if they are not true and authentic. POS researchers trace back authenticity to ancient times and modernism. Positive psychologists conceive authenticity as both owning one's personal experiences (thoughts, emotions, beliefs) and acting in accord with the true self (behaving and expressing what you really think and believe) (Harter, 2002). Therefore, authentic leadership is purely based on authenticity, authentic leaders do not try to coerce or even rationally persuade associates, but rather the leader's authentic values, beliefs, and behaviours serve to model the development of associates. 
Authentic leadership is an approach to leadership that emphasizes building the leader's legitimacy through honest relationships with followers which value their input and are built on an ethical foundation. Generally, authentic leaders are positive people with truthful self-concepts who promote openness. By building trust and generating enthusiastic support from their subordinates, authentic leaders are able to improve individual and team performance. Luthans and Avolio (2003) provide a wide range of characteristics of authentic leaders. They are confident, hopeful, optimistic, resilient, transparent, moral/ethical, future-oriented and associate building. However, perhaps the most robust model of authentic leadership was proposed by Walumbwa, Avolio, Gardner, Wernsing and Peterson (2008). They highlight and introduce a measure of four principles of authentic leadership: (1) self-awareness: an ongoing process of reflection and reexamination by the leader of own strength, weaknesses, and values; (2) relational transparency: open sharing by the leader of own thoughts and beliefs, balanced by a minimization of inappropriate emotions; (3) balanced processing: solicitation by the leader of opposing viewpoints and fair-minded consideration of those viewpoints; and (4) internalized moral perspective: a positive ethical foundation adhered to by the leader in relationships and decisions that is resistant to outside pressures.

A careful analysis of the dimensions of authentic leadership brings to a conclusion that the concept partly overlaps with some previous approaches, namely transformational leadership and emotional intelligence. With the first concept it shares balanced processing that corresponds to individual consideration. Emotional intelligence brings to authentic leadership self-awareness and empathy that corresponds to balanced processing.

Another positive concept of leadership that was created a little bit later by Quinn (2005) and is more difficult to grasp is fundamental state of leadership. The essence of it is answering four questions: "Am I results centred? (Am I willing to leave my comfort zone to make things happen?) Am I internally directed? (Am I behaving according to my values rather than bending to social or political pressures?) Am I other focused? (Am I putting the collective good above my own needs?) Am I externally open? (Am I receptive to outside stimuli that may signal the need for change?)" (Quinn, 2005, p. 75). Quinn claims that "asking and answering these questions tends to change the being state. New feelings, thoughts, behaviours, and techniques then emerge. The person makes deep change and exerts new patterns of influence." (Quinn \& Anding, 2005, pp. 489-490).

However, the critical question in reaching fundamental state of leadership is: Who am I? (What are my values? What would I never compromise?). In this sense fundamental state of leadership draws from emotional intelligence self-awareness being the basic component. Also other focus is based on one of the components of emotional intelligence - empathy.

Quinn (2005) opposes fundamental state of leadership to ordinary state. He also argues that "people who observe excellence from the normal state see only what their conceptual tools allow them to see. (...) Normal thinking, based on the assumptions of transaction and analyses is going to capture the part and not the whole. Normal thinking lacks the requisite variety, the complexity to capture what is there." (Quinn \& Anding, 2005, p. 494). Therefore, fundamental state of leadership should be treated as a higher 
state of awareness, that, however, can be achieved by combining four components: (1) results orientation, (2) internal direction, (3) other focus, and (4) external openness. Two more attributes of fundamental state of leadership should be noticed. First, Quinn argues that it might not be fully conscious. People could enter fundamental state of leadership without even knowing it. Second, it is a temporary state. People enter and exit it as victims of entropy.

The final concept that can be qualified as positive leadership theory is positive deviance. Originally it was created as an approach to behavioural and social change based on the observation that in any community, there are people whose uncommon but successful behaviours or strategies enable them to find better solutions to a problem than their peers, despite facing similar challenges and having no extra resources or knowledge than their peers. These individuals are referred to as positive deviants (Tuhus-Dubrow, 2009). To augment positive deviance from the individual to the firm level, the operational definition of corporate deviance consists of three specific and measurable components: intentionality, departure from referent group norms, and of either a harmful or an honourable nature. Positive deviant behaviour, by definition, has to be "voluntary, purposeful, and discretionary, rather than forced or coerced" (Spreitzer \& Sonnenshein, 2004, p. 842).

The most comprehensive model of positive deviance was presented by Cameron (2008). He states that positive leadership: (1) refers to the facilitation of positively deviant performance, (2) refers to an affirmative bias, and (3) focuses on facilitating the best of the human condition, or on fostering virtuousness. Cameron also presents four leadership strategies that enable positive deviance: (1) positive climate (fostering compassion, forgiveness and gratitude), (2) positive relationships (building energy networks and reinforcing strengths), (3) positive communication (obtaining best-self feedback and using supportive communication), and (4) positive meaning (affecting human well-being, connecting to personal values, highlighting extended impact and building community) (Figure 1). Enhancing one of the strategies tends to positively impact the other three.

\section{Psychological Capital}

Luthans and Avolio (2003) define authentic leadership in organisations as a process that draws from positive psychological capacities and a highly developed organisational context, which results in both greater self-awareness and self-regulated positive behaviours on the part of leaders and followers, fostering positive self-development. By positive psychological capacities they understand mainly psychological capital (PsyCap), construct that replaced positive psychological capacities a year later (Luthans \& Youssef, 2004). This composite construct has been defined as "an individual's positive psychological state of development and is characterized by: (1) having confidence (self-efficacy) to take on and put in the necessary effort to succeed at challenging tasks; (2) making a positive attribution (optimism) about succeeding now and in the future; (3) persevering toward goals and, when necessary, redirecting paths to goals (hope) in order to succeed; and (4) when beset by problems and adversity, sustaining and bouncing back and even beyond (resilience) to attain success" (Luthans, Youssef \& Avolio, 2007, p. 3). It should be also emphasized here, that there has been a discussion going on about what psychological capital really is: more a trait or more a state. Luthans, Avolio, Avey and Norman (2007, p. 544) argue that on the continuum from trait, through trait-like and state-like to 
state, it is state-like, "relatively malleable and open to development; the constructs could include not only efficacy, hope, resilience, and optimism, but also a case has been made for positive constructs such as wisdom, well-being, gratitude, forgiveness, and courage as having "state-like" properties as well".

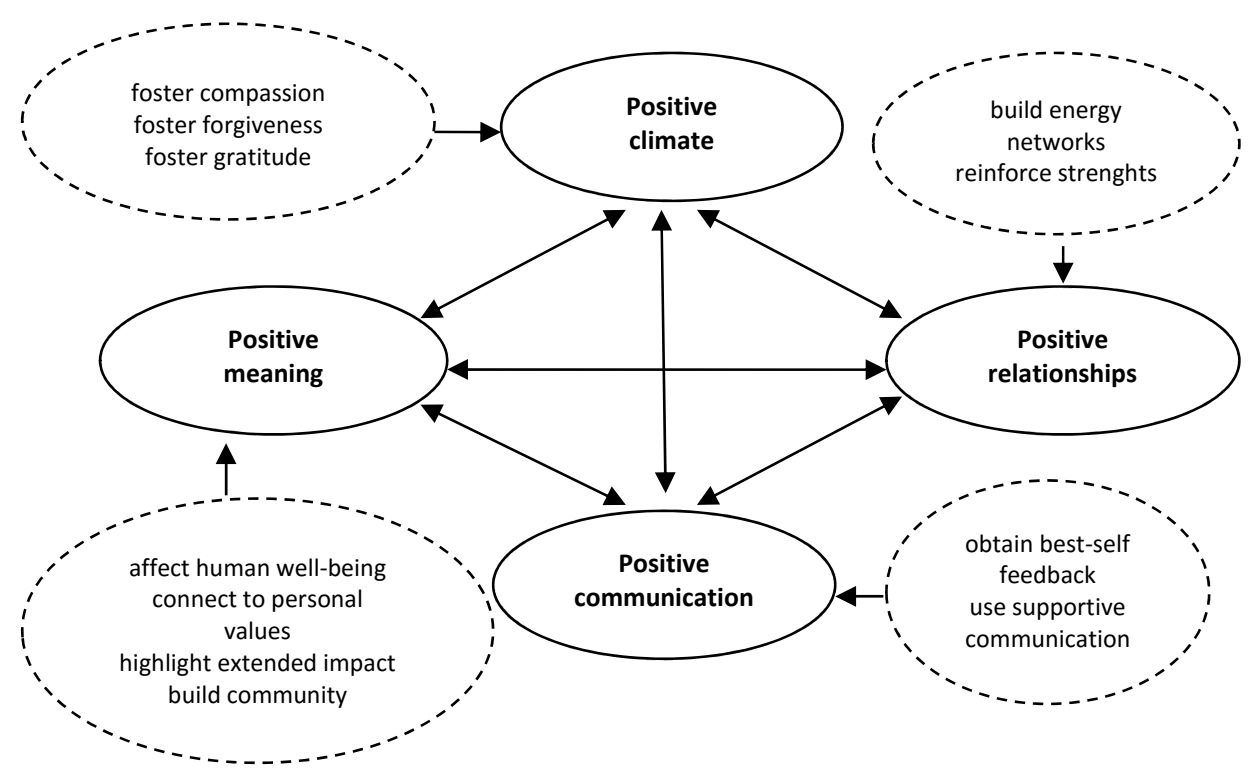

Figure 1. Four leadership strategies that enable positive deviance Source: Cameron (2008, p. 14).

\section{Impact of Positive Leadership on Corporate Entrepreneurship}

For some scholars the essence of corporate entrepreneurship and a source of entrepreneurial behaviour at organisational level is entrepreneurial orientation. It is an ideology that generate strategic criteria of importance, desirability, feasibility, legitimacy, relevance of opportunities and actions. Moreover it channels and distributes decision making into a specific set of procedures and practices. Finally, it provides the institutional strategic framework for understanding the situations that motivate action and interpret meaning. Some researchers operationalized the behaviour of entrepreneurial firms as consisting of product-market innovation, proactiveness of decision making, and risktaking. They maintained that the level of entrepreneurship presented by a firm was the aggregate total of these three sub-dimensions: "the extent to which top managers are inclined to take business-related risks (the risk-taking dimension), to favour change and innovation in order to obtain a competitive advantage for their firm (the innovative dimension), and to compete aggressively with other firms (the proactive dimension)" (Covin \& Slevin, 1988, p. 218). Entrepreneurial orientation has been later operationalized as five-dimensional construct (Lumpkin \& Dess, 1996) or three-dimensional one (Kreiser, Marino \& Weaver, 2002) and a prerequisite and critical factor of corporate entrepreneurship. In the project corporate entrepreneurship will be conceptualized as a construct which dimensions work in configuration with positive behaviours in the process of mod- 
eration between high performance factors and the actual performance of the organisation.

The question on supporting corporate entrepreneurship by applying positive leadership is an important one, as researchers and business practitioners are looking for new ways of supporting innovativeness, proactiveness and willingness to take risk. It should be noted here, that positive leadership and corporate entrepreneurship are concepts at different levels of analysis. Positive leadership is typically analyzed at individual level and corporate entrepreneurship at organisational level. Therefore, supporting entrepreneurial orientation by creating positive leadership should be directed at institutional solutions: recruiting and training positive leaders. Moreover, the effects of such processes might not be homogenous within the entire organisation - the level of corporate entrepreneurship might differ according to the degree of 'positivity' of local leader.

The impact of psychological capital on entrepreneurship is perhaps the most widely investigated among approaches to positive leadership. For example Hayek (2012) states that while the constructs that form the psychological capital construct, hope, resilience, optimism, and self-efficacy are all revered characteristics and highly associated with entrepreneurs, the consequences of these being applied to situations where the individual actually has a misplaced sense of control may have dire consequences. In broader sense, psychological capital might contribute to corporate entrepreneurship in a number of ways. Self-efficacy allows pursuing risky and difficult business opportunities, hope and optimism allow to interpret strategic events as opportunities instead of threats (Bratnicki, 2006) and resilience allows to continue to further develop ventures in the environment of pressure and crisis. Therefore, I propose that:

Proposition 1: Psychological capital of managers contributes to corporate entrepreneurship.

There is no empirical evidence on the impact of authentic leadership on corporate entrepreneurship. However, this kind of contribution can be assumed, taking into consideration the components of authentic leadership. The assumed influence especially concerns the followers of authentic leader and the component most likely to be of importance here is balanced processing. It allows employees to express their opinions, which, in turn allows for bottom-up creation of new ventures. Moreover, Hmieleski, Cole and Baron (2012) in their study of top management teams of new ventures and their impact on performance state that authentic leadership may be particularly beneficial when shared among team members. Therefore, I propose that:

Proposition 2: Authentic leadership of managers contributes to corporate entrepreneurship.

Similarly, there is no evidence on relationship between fundamental state of leadership and corporate entrepreneurship. Also in this case components of the concept might be relevant for corporate entrepreneurship, especially other focus and external openness. The first of them introduces the atmosphere of respect and understanding that is necessary for the development of new ventures. External openness is in turn important for receiving information and inspiration for new ventures. It constitutes a phenomenon by some called entrepreneurial alertness. Therefore: 
Proposition 3: Fundamental state of leadership of managers contributes to corporate entrepreneurship.

Finally, positive deviance is expected to contribute to corporate entrepreneurship. I argue that the entire concept of positive deviance is entrepreneurial, as it means doing something in a different, extraordinary and new way. The same principles lie at the core of entrepreneurship, including corporate entrepreneurship. Unfortunately, there is no empirical evidence on the support for corporate entrepreneurship from positive deviance. The only partial piece of evidence comes from Nam, Parboteeah, Cullen and Johnson (2014) who argue that innovation is an outcome of positive deviance. I therefore propose that:

Proposition 4: Positive deviance of managers contributes to corporate entrepreneurship.

\section{CONCLUSIONS}

The field of positive leadership and its relations with phenomena at organisational level is largely under-researched. I argue that this line of study has a huge potential and might be fruitful in explaining firm level entrepreneurship at scientific level and supporting it at practical level. So far, the field is characterized by high degree of complexity and disorder. What is critical in this line of research, is the configuration of positive leadership approaches and its combined impact on corporate entrepreneurship. There is some empirical evidence that positive leadership types work in synergy and reinforce each other. For instance Jensen and Luthans (2006) argue that psychological capital supports entrepreneurs' authentic leadership. Therefore relationships in this area should be investigated comprehensively, with regard to other approaches.

There is an important question on the level of analysis of impact of positive leadership on corporate entrepreneurship. It might be studies on individual level, where positive behaviours of the leader contribute to his entrepreneurial spirit, which in turn mobilizes the followers to develop new ventures. On the other hand, positive leadership taken to organisational level might directly contribute to entrepreneurial orientation of the whole organisation. Important argument for the second approach is delivered by Memili, Welsh and Luthans (2013, p. 1291) who introduce the concept of organisational psychological capital (OPC) arguing that "group-level collective PsyCap can develop through interactive and coordinative dynamics and leadership in a firm that can foster desired behaviours and performance outcomes".

The main weakness of the study is the lack of literature in the field of positive leadership. The paper is therefore based on available literature sources that might not be fully exhaustive. The main contribution of the paper is to draw attention to the models of leadership that might be critical for entrepreneurship inside organisations. That question, however, goes beyond that and also considers individual entrepreneurship and leadership skills necessary to start up and develop an enterprise. 


\section{REFERENCES}

Bass, B. (2000). The future of leadership in learning organizations. Journal of Leadership Studies, 7(3), 18-40.

Bass, B.M. (1985). Leadership and performance beyond expectations. New York: Free Press.

Bratnicki, M. (2006). The dialectics of organizational entrepreneurship. Katowice: University of Economics in Katowice.

Burns, J.M. (1978). Leadership. New York: Harper \& Row.

Cameron, K.S. (2008). Positive leadership. Strategies for extraordinary performance. San Francisco: Berrett Koehler.

Cameron, K.S., Dutton, J.E., \& Quinn, R.E. (2003). Positive organizational scholarship. Foundations of a new discipline. San Francisco: Berrett-Koahler Publishers, Inc.

Cameron, K.S., \& Spreitzer, G.M. (Eds.) (2012). The Oxford handbook of positive organizational scholarship. Oxford/New York: Oxford University Press.

Covin, J.G., \& Slevin, D.P. (1988). The influence of organization structure on the utility of an entrepreneurial top management style. Journal of Management Studies, 25(3), 217-234.

Greenleaf, R. (1977). Servant-leadership: A journey into the nature of legitimate power and greatness. New York: Paulist Press.

Harter, S. (2002). Authenticity. In C.R. Snyder \& S.J. Lopez (Eds.), Handbook of positive psychology (pp. 382-394). Oxford, UK: Oxford University Press.

Hayek, M. (2012). Control beliefs and positive psychological capital: Can nascent entrepreneurs discriminate between what can and cannot be controlled? Journal of Management Research, 12(1), 3-13.

Hmieleski, K.M., Cole, M.S., \& Baron, R.A. (2012). Shared authentic leadership and new venture performance. Journal of Management, 38(5), 1476-1499.

Jensen, S.M., \& Luthans, F. (2006). Relationship between entrepreneurs' psychological capital and their authentic leadership. Journal of Managerial Issues, 18(2), 254-273.

Kreiser, P.M., Marino L., \& Weaver, K.M. (2002). Assessing the psychometric properties of the entrepreneurial orientation scale: A multi-country analysis. Entrepreneurship Theory and Practice, 26(4), 71-94.

Levie, J. (2016). What drives entrepreneurship inside organisations? Paper presented at 2016 ENTRE Conference in Kraków.

Lumpkin, G.T., \& Dess, G.G. (1996). Clarifying the entrepreneurial orientation construct and linking it to performance. Academy of Management Journal, 21(1), 135-172.

Luthans, F., \& Avolio, B. (2003). Authentic leadership development. In K.S. Cameron, J.E. Dutton \& R.E. Quinn (Eds.), Positive organizational Scholarship. Foundations of a new discipline (pp. 241-258). San Francisco: Berrett-Koehler Publishers.

Luthans, F., Avolio, B.J., Avey, J.B., \& Norman, S.M. (2007). Positive psychological capital: Measurement and relationship with performance and satisfaction. Personnel Psychology, 60, 541572.

Luthans, F., \& Youssef, C.M. (2004). Human, social, and now positive psychological capital management. Organizational Dynamics, 33, 143-160.

Luthans, F., Youssef, C.M., \& Avolio, B.J. (2007). Psychological capital. New York: Oxford University Press. 
Memili, E., Welsh, D.H.B., \& Luthans, F. (2013). Going beyond research on goal setting: A proposed role of organizational psychological capital of family firms. Entrepreneurship Theory and Practice, 37, 1289-1295.

Nam, D., Parboteeah, K.P., Cullen, J.B., \& Johnson, J.L. (2014). Cross-national differences in firms undertaking innovation initiatives: An application of institutional anomie theory. Journal of International Management, 20(2), 91-106.

Piccolo, R.F., \& Colquitt, J.A. (2006). Transformational leadership and job behaviors: The mediating role of core job characteristics. Academy of Management Journal, 49(2), 327-340.

Quinn, R.E. (2005). Moments of greatness: Entering the fundamental state of leadership. Harvard Business Review, July-August, 75-83.

Quinn, R.E., \& Anding, J.M. (2005). An Interview with Robert E. Quinn Entering the fundamental state of leadership: Reflections on the path to transformational teaching. Academy of Management Learning \& Education, 4(4), 487-495.

Spreitzer, G.M., \& Sonnenschein, S. (2004). Toward the construct definition of positive deviance. American Behavioral Scientist, 47, 828-847.

Tuhus-Dubrow, R. (2009). The Power of Positive Deviants: A promising new tactic for changing communities from the inside. Boston Globe. November 29.

Walumbwa, F.O., Avolio, B.J., Gardner, W.L., Wernsing, T.S., \& Peterson, S.J. (2008). Authentic leadership: Development and validation of a theory-based measure. Journal of Management, 34, 89-126. 


\section{Author}

\section{Przemysław Zbierowski}

Associate Professor at the Department of Entrepreneurship at the University of Economics in Katowice. His research interests focus on entrepreneurship, positive organisational scholarship and high organisational performance. He is the author of more than 120 academic papers. He is also a member of several international academic organizations, such as Academy of Management, British Academy of Management, Institute for Small Business and Entrepreneurship, Welsh Enterprise Institute, and the national team leader for Poland within Global Entrepreneurship Monitor project. He is a teacher, trainer and consultant in the field of entrepreneurship, leadership, organizational behaviour, international management and strategic management. He has an experience of working with students at various levels of education (from undergraduate to MBA) and with senior managers and top management teams. He is also actively involved in business practice by being co-owner and member of the board of an IT company; he assisted in start-ups of a number of businesses and has experience of being a member of supervisory board of a few companies.

Correspondence to: Prof. UE dr hab. Przemysław Zbierowski; University of Economics in Katowice; Department of Entrepreneurship; ul. 1 Maja 50; 40-287 Katowice, Poland; e-mail: przemysław.zbierowski@ue.katowice.pl

\section{Acknowledgements and Financial Disclosure}

The research was carried out within the research project no. 2014/13/B/HS4/01618 funded by National Science Centre (NCN) in Poland.

\section{Copyright and License}

This article is published under the terms of the Creative Commons Attribution - NonCommercial - NoDerivs (CC BY-NC-ND 3.0) License http://creativecommons.org/licenses/by-nc-nd/3.0/ 